\title{
Experiment Investigation on Electrical and Thermal Performances of a Semitransparent Photovoltaic/Thermal System with Water Cooling
}

\author{
Guiqiang Li, Gang Pei, Ming Yang, and Jie Ji \\ Department of Thermal Science and Energy Engineering, University of Science and Technology of China, 96 Jinzhai Road, \\ Hefei City 230026, China \\ Correspondence should be addressed to Gang Pei; peigang@ustc.edu.cn
}

Received 25 March 2014; Accepted 2 July 2014; Published 1 September 2014

Academic Editor: Hongxing Yang

Copyright (C) 2014 Guiqiang Li et al. This is an open access article distributed under the Creative Commons Attribution License, which permits unrestricted use, distribution, and reproduction in any medium, provided the original work is properly cited.

\begin{abstract}
Different from the semitransparent building integrated photovoltaic/thermal (BIPV/T) system with air cooling, the semitransparent $\mathrm{BIPV/T}$ system with water cooling is rare, especially based on the silicon solar cells. In this paper, a semitransparent photovoltaic/thermal system (SPV/T) with water cooling was set up, which not only would provide the electrical power and hot water, but also could attain the natural illumination for the building. The PV efficiency, thermal efficiency, and exergy analysis were all adopted to illustrate the performance of SPV/T system. The results showed that the PV efficiency and the thermal efficiency were about $11.5 \%$ and $39.5 \%$, respectively, on the typical sunny day. Furthermore, the PV and thermal efficiencies fit curves were made to demonstrate the SPV/T performance more comprehensively. The performance analysis indicated that the SPV/T system has a good application prospect for building.
\end{abstract}

\section{Introduction}

Building integrated photovoltaic/thermal (BIPV/T) is one of the most applicable solutions for solar PV. For BIPV/T, it can take away the heat from PV cells to keep a high electrical efficiency and then supply the electrical power and heat source for the building. Chow et al. indicated that the limited building space for accommodating solar devices has driven a demand on the use of PV/T technology [1]. Ooshaksaraei et al. illustrated the characterization of airbased photovoltaic/thermal panels with bifacial solar cells [2]. J. H. Kim and J. T. Kim took the experiment on the performance of an unglazed PV/T collector with two different absorber types [3]. Matuska investigated the influence of building integration of polycrystalline PV modules on their performance and potential for use of active liquid cooling by use of BIPV-T collectors through simulation analysis [4]. Nonetheless considering the comfort and the architectural lighting, as the facade or roof in building, the BIPV/T still needed to maintain the natural lighting of the building spaces.
It is known for BIPV that the transparency of the PV system is realised by either thin PV cells becoming transparent or leaving spaces between the PV cells to allow the natural illumination partially into the building [5]. Kang et al. used the dye-sensitized solar cells (DSCs) to replace building windows which allowed light transmission and application of various colors but had a lower efficiency in terms of electricity generation than silicon solar cells [6].

However, due to the cooling structure, it is more difficult for BIPV/T to maintain the natural lighting of the building spaces than BIPV. Many researchers improved BIPV/T to achieve this purpose. For BIPV/T with air cooling, Vats et al. designed a building integrated semitransparent photovoltaic/thermal (BISPVT) system for roof and facade which could provide electricity, space heating, and day lighting [7-9]. Kamthania et al. presented the performance evaluation of a hybrid photovoltaic/thermal (Semitransparent PV/T) double pass facade for space heating [10]. But for BIPV/T with water cooling, less work has been focused on the semitransparent photovoltaic/thermal system, which is due 
TABLE 1: Area size of the SPV/T.

\begin{tabular}{lc}
\hline Component & Area size $\left(\mathrm{m}^{2}\right)$ \\
\hline PV & 0.112 \\
Total area (excluding gap) & 0.27 \\
\hline
\end{tabular}

to the common whole flat plate $\mathrm{PV} / \mathrm{T}$ process technology with water cooling. Suppose that a semitransparent photovoltaic/thermal system (SPV/T) with water cooling was built, it not only would provide the electrical power, space heating, and hot water for the building, but also could attain the natural illumination, which would further expand the application scope of the BIPV/T.

Therefore, this paper presented a semitransparent photovoltaic/thermal system with water cooling for building application through improving the PV/T structure. The system adopted a technology that the PV was directly laminated on the surface of the square tube, and the space was left between square tubes. The schematic diagram of the semitransparent photovoltaic/thermal system with water cooling on a roof was shown in Figure 1 and the sunlight can be allowed through the gap into the building space. Considering that the crystalline silicon PV has a higher electrical efficiency than other solar PVs, thus the semitransparent photovoltaic/thermal system adopted the crystalline silicon PV to obtain a higher PV power. The experiment focused on the electrical and thermal performances of the SPV/T system, which indicated that the SPV/T system has a good PV/T performance.

\section{Experimental Rig Setup}

2.1. SPV/T Solar Collector Structure. The SPV/T consisted of $\mathrm{PV}$, the cooling square tube, the storage tank, the connecting pipe, and other major components. The constituent layers of PV/T were shown in Figure 2(a). The PV was inserted within the encapsulated materials, which included the transparent TPT (tedlar polyester-tedlar) and the EVA (ethylene-vinyl acetate) layers on the top, and the EVA and opaque TPT layers underneath. TPT is known for its good electrical insulation and EVA is the adhesive material. Further down the square pipe is a layer of thermal insulation, which covered the two side surfaces and bottom surfaces of the square pipe. There is an insulated air layer between the front glazing and the PV encapsulation, the same as that between the back glazing and the thermal insulation layer.

Four PV cells were connected in series and laminated together on one square tube. The size of each PV cell is $15.6 \mathrm{~cm} * 1.0 \mathrm{~cm}$ and that of the square pipe is $80.0 \mathrm{~cm} * 1.5 \mathrm{~cm}$. The SPV/T system has 18 square pipes (Figure 2(b)). The real photo of SPV/T was shown in Figure 3(c), and the sunlight can pass through the spaces between the square pipes to reach the ground.

Other size parameters of this SPV/T system were shown in Table 1.

2.2. Experimental Test Device. The SPV/T system cooperated with a maximum power point tracker (MPPT); thus the output value of PV could maintain at its maximum value.

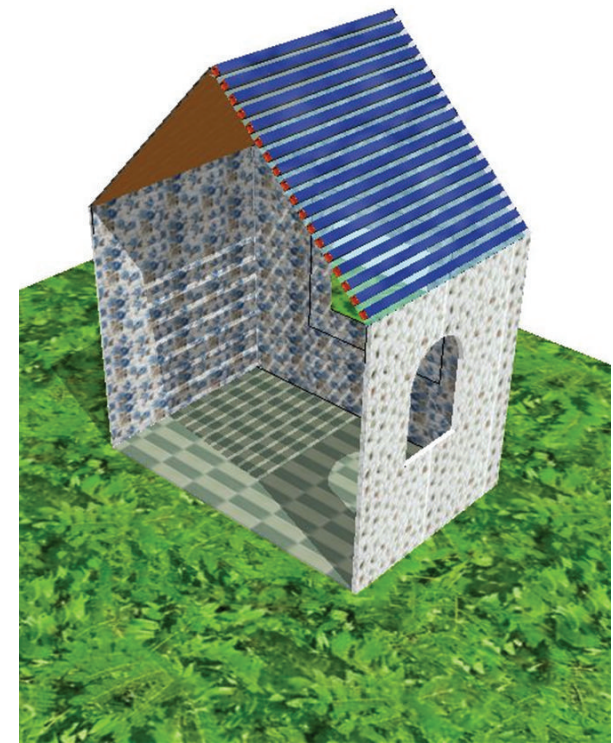

FIGURE 1: Schematic diagram of the SPV/T with water cooling on a roof.

During operation, the cooling water was circulated from the bottom port of the storage tank, then entered into the lower inlet of the SPV/T collector and took away the heat from the PV, at last outflowed from the upper outlet of the SPV/T collector, and returned to the top port of the storage tank. A $1.5 \mathrm{~W}$ mini water pump was installed as an auxiliary loop tool, and the flow rate was approximately $0.031 \mathrm{~m}^{3} / \mathrm{h}$. The volume of water tank was $20 \mathrm{~L}$. Three thermocouples were vertically and symmetrically arranged in the tank to test the water temperature in the storage tank. The ambient temperature and wind speed were measured by ambient monitor. The components of the test equipment are listed in Table 2.

\section{Testing and Evaluation of the Semitransparent Photovoltaic/Thermal System}

3.1. Experimental Test Profile. The prototype of the SPV/T system was designed and installed on a rooftop at University of Science and Technology of China in Hefei $\left(31^{\circ} 53^{\prime} \mathrm{N}\right.$, $\left.117^{\circ} 15^{\prime} \mathrm{E}\right)$. The orientation of the system was facing south at a $32^{\circ}$ tilt angle.

3.2. Evaluation Performance of SPV/T System. The electrical efficiency of $\mathrm{PV}$ from the experiment was given:

$$
\eta_{\mathrm{sys}, \mathrm{pv}}=\frac{I_{m} \cdot V_{m}}{G \cdot A_{\mathrm{pv}}}
$$

where $I_{m}$ and $V_{m}$ are the current and the voltage of the PV operating at the maximum power; $G$ is the total solar radiation, $\mathrm{Wm}^{-2} ; A_{\mathrm{pv}}$ is $\mathrm{PV}$ area, $\mathrm{m}^{2}$. 


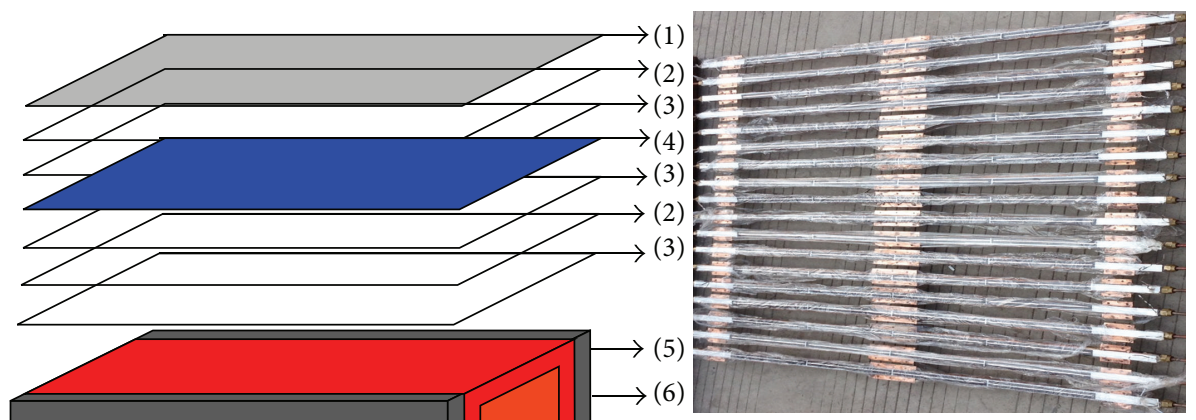

(b)
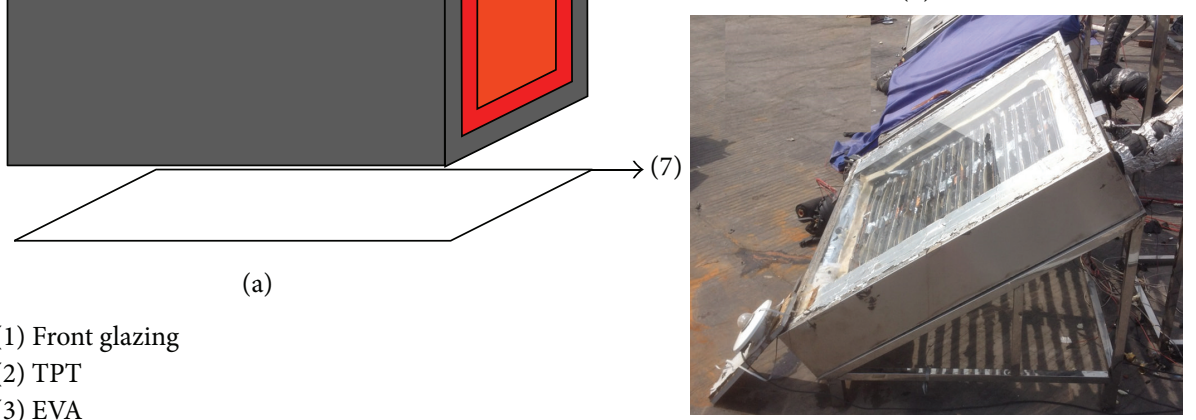

(1) Front glazing

(2) TPT

(3) EVA

(4) PV module

(5) Square pipe

(C)

(6) Thermal insulation

(7) Back glazing

FIGURE 2: SPV/T structure: (a) constituent layers of PV/T, (b) PV/T, and (c) photo of SPV/T solar collector.

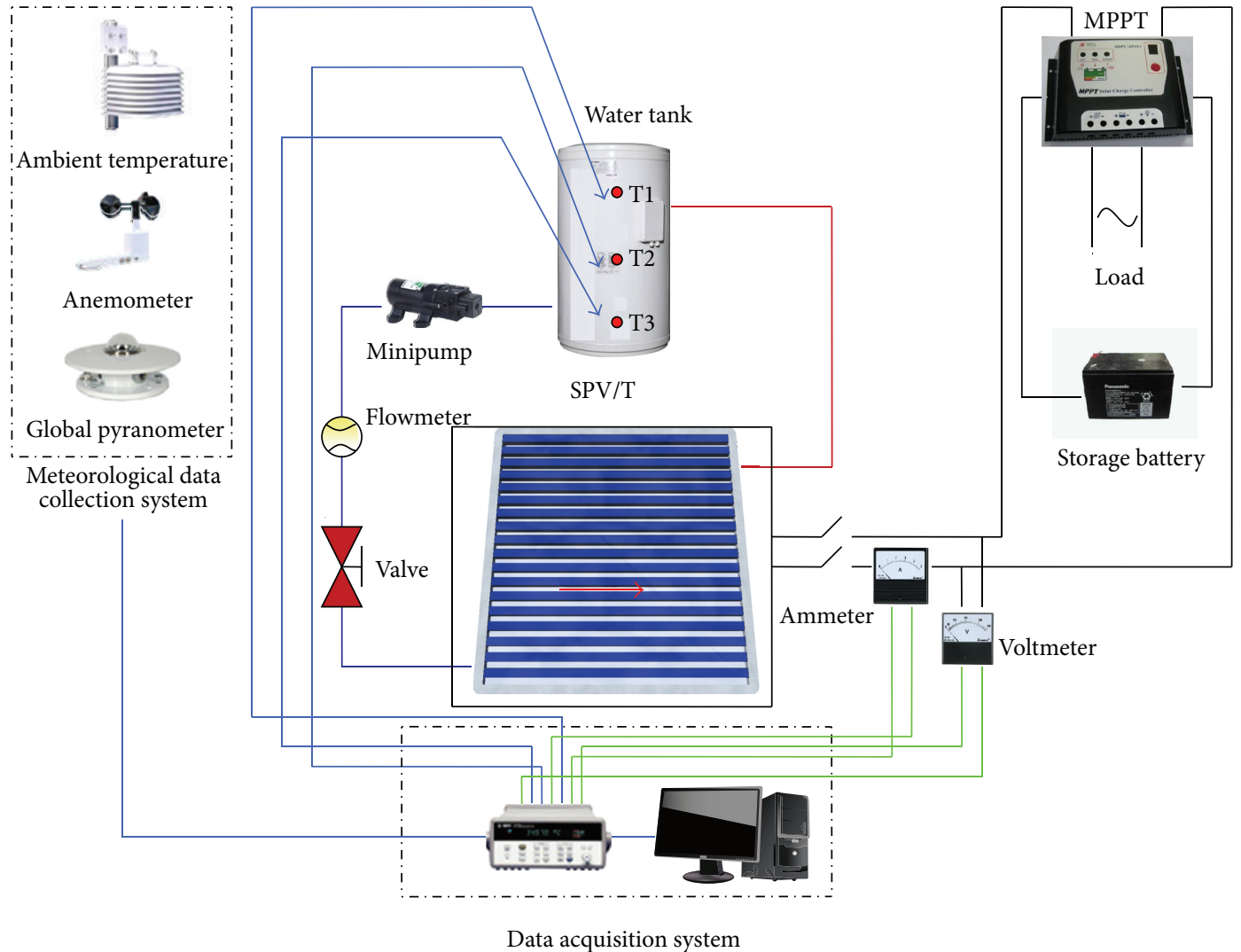

FIgURE 3: Testing schematic diagram of SPV/T system. 
TABLE 2: Specification of the test components.

\begin{tabular}{lcccc}
\hline Test equipment & Specification & Suppliers names & Quantity & Position \\
\hline Ultrasonic flowmeter & TUF-2000P & $\begin{array}{c}\text { Shanghai Juguan Industry } \\
\text { Automation Device Ltd. }\end{array}$ & 1 & Main pipe line \\
Thermocouple & $0.2 \mathrm{~mm}$ copper-constantan & Homemade & 3 & Water tank \\
Pyranometer & TBQ-2 & Jinzhou, China (Sun Co.) & 1 & $\begin{array}{c}\text { Near experimental rig with } \\
\text { the same tilted angle }\end{array}$ \\
$\begin{array}{l}\text { Minipump } \\
\text { Ambient monitor }\end{array}$ & $\sim 1.5 \mathrm{KW}$ & Homemade & 1 & Main pipe line \\
& JZH-1 & Jinzhou, China (Sun Co.) & 1 & Near experimental rig \\
& Others: data acquisition instrument: Agilent 34970A (USA), test computer, electrical wires, etc.
\end{tabular}

For the SPV/T system, the heating capacity obtained by the water in the tank can be expressed as follows:

$$
\dot{Q}_{\text {sys,th }}=m_{w_{-} \operatorname{tank}} c \frac{d \bar{T}}{d t},
$$

where $\bar{T}$ is the average water temperature in the tank, ${ }^{\circ} \mathrm{C}$.

The system thermal efficiency $\eta_{\text {sys,th }}$ is calculated by

$$
\eta_{\text {sys,th }}=\frac{\int_{t_{1}}^{t_{2}} \dot{Q}_{\text {sys,th }} d t}{A_{c} \int_{t_{1}}^{t_{2}} G d t}
$$

$\eta_{\text {sys,th }}$ can also be obtained by

$$
\begin{aligned}
\eta_{\text {sys,th }} & =\alpha_{0}-U_{s} T_{i}^{*} \\
& =\alpha_{0}-U_{s} \frac{T_{i}-\bar{T}_{a}}{\bar{G}},
\end{aligned}
$$

where $\bar{G}$ is the average solar radiation, $\mathrm{Wm}^{-2}$, and $A_{c}$ is the total area of the collector.

The exergy efficiency can be defined to describe the quality difference between electricity and heat. The exergy analysis method was based on the second law of thermodynamics, which revealed a system with a reasonable degree of energy and could evaluate the system performance better.

The exergy efficiency of PV unit conversion is defined as

$$
\varepsilon_{\mathrm{sys}, \mathrm{pv}}=\frac{I_{m} \cdot V_{m}}{G \cdot A_{\mathrm{pv}} \cdot \varphi_{\mathrm{srad}, \max }},
$$

where $\varphi_{\text {srad,max }}$ is the maximum efficiency ratio for determining the exergy of thermal emission at temperature $T[11,12]$ and the expression is

$$
\varphi_{\text {srad,max }}=1+\frac{1}{3}\left(\frac{T_{a}}{T}\right)^{4}-\frac{4}{3} \frac{T_{a}}{T},
$$

where $T$ is equal to the $6000 \mathrm{~K}$ solar radiation temperature in the exergetic evaluation.

The exergy efficiency of thermal conversion is defined as

$$
\varepsilon_{\text {sys }}=\frac{\int_{t_{1}}^{t_{2}}\left(\dot{E}_{X_{\text {output }}}-W_{\text {pump }}\right) d t}{\int_{t_{1}}^{t_{2}} \dot{E}_{X_{\text {sun }}} d t},
$$

where the exergy obtained in the storage tank could be written as follows [13], and assuming that the temperature value in the tank is the arithmetic average of three thermocouple temperature values:

$$
\dot{E}_{X_{\text {output }}}=\dot{Q}_{\text {sys,th }}\left(1-\frac{T_{a}}{\bar{T}}\right),
$$

$\dot{E}_{X_{\text {sun }}}$ is the exergy from the sun and could be written as

$$
\dot{E}_{X_{\text {sun }}}=A_{c} G \varphi_{\text {srad,max }} .
$$

\section{Experimental Results and Discussion}

4.1. Performance Analysis on a Typical Sunny Day. A typical day as an example, the test time was from 8:00 to 15:30. The environmental parameters during the test were shown in Figure 4 . The average solar radiation and the average ambient temperature were $729.0 \mathrm{Wm}^{-2}$ and $16.9^{\circ} \mathrm{C}$, respectively. The average wind speed was approximately $1.5 \mathrm{~ms}^{-1}$.

According to (1) and (2), the instantaneous PV efficiency and thermal efficiency can be obtained, as shown in Figure 5. The value of PV efficiency was between 0.095 and 0.13 . The tendency of the PV efficiency curve was gradually declined during the test which was because the water temperature became higher. For thermal efficiency, the instantaneous values increased at first and then gradually declined. The maximum value of the thermal efficiency was $53.0 \%$. The overall PV efficiency and the thermal efficiency on whole day were about $11.5 \%$ and $39.5 \%$, respectively.

It is clear that for the SPV/T system, the exergy efficiency of the PV was much higher than that of the hot water (Figure 6). That is because in the SPV/T system applications the production of electricity is the main priority, and it is necessary to operate the PV modules at a low temperature. The water was heated from $19.4^{\circ} \mathrm{C}$ to $44.5^{\circ} \mathrm{C}$ during the test. Before 8:30, the water temperature increased slowly, and the exergy efficiency of the thermal output was below $1 \%$ and the highest exergy efficiency of the thermal output was between $12: 30$ and 13:00, and the maximum value was about $2.85 \%$.

4.2. SPV/T Performance Curve Fitting. Referring to [14], in order to apprehend the electrical and thermal performance of the SPV/T system under the forced flow situation, Case 1Case 11 on the experiment with different initial temperatures 


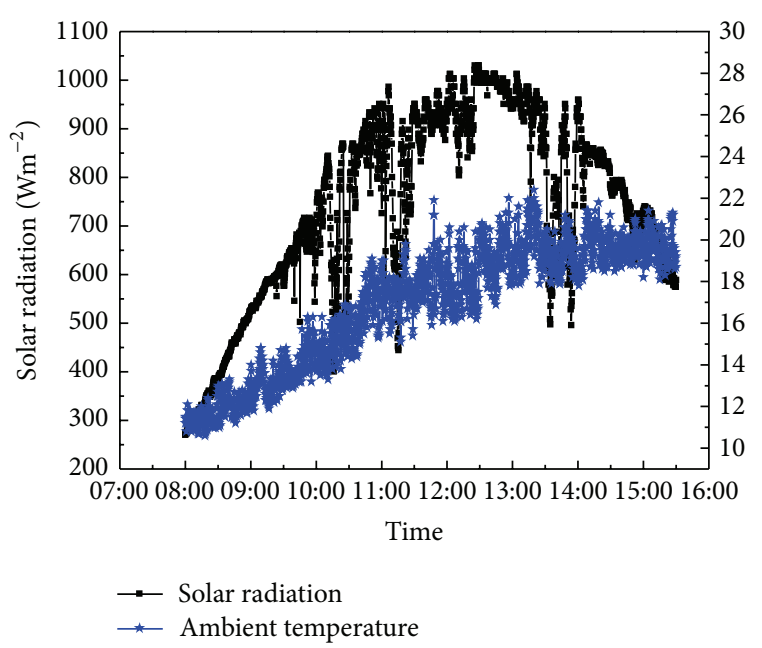

FIGURE 4: Environmental parameters during the test.

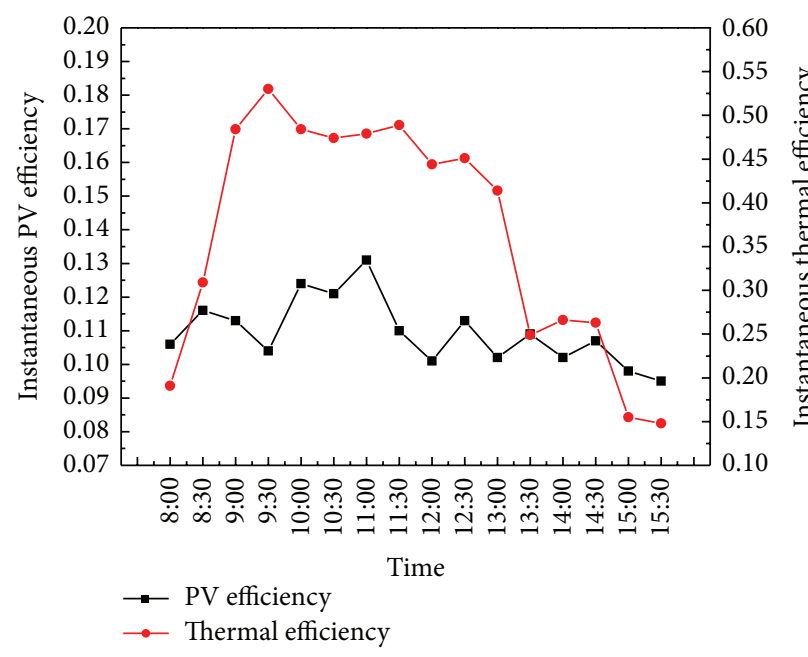

FIGURE 5: PV and thermal efficiency during the test.

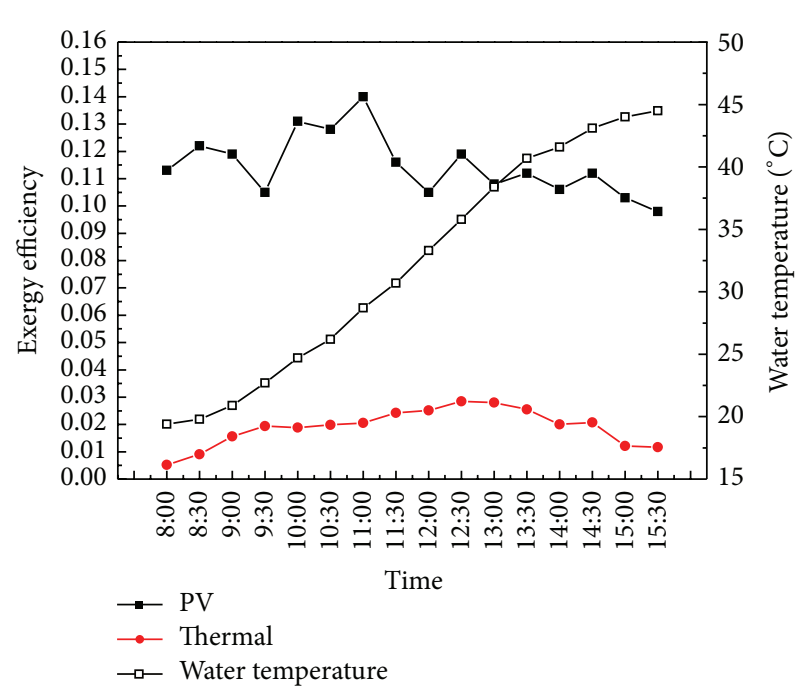

FIGURE 6: Exergy efficiency with water temperature variation during the test.

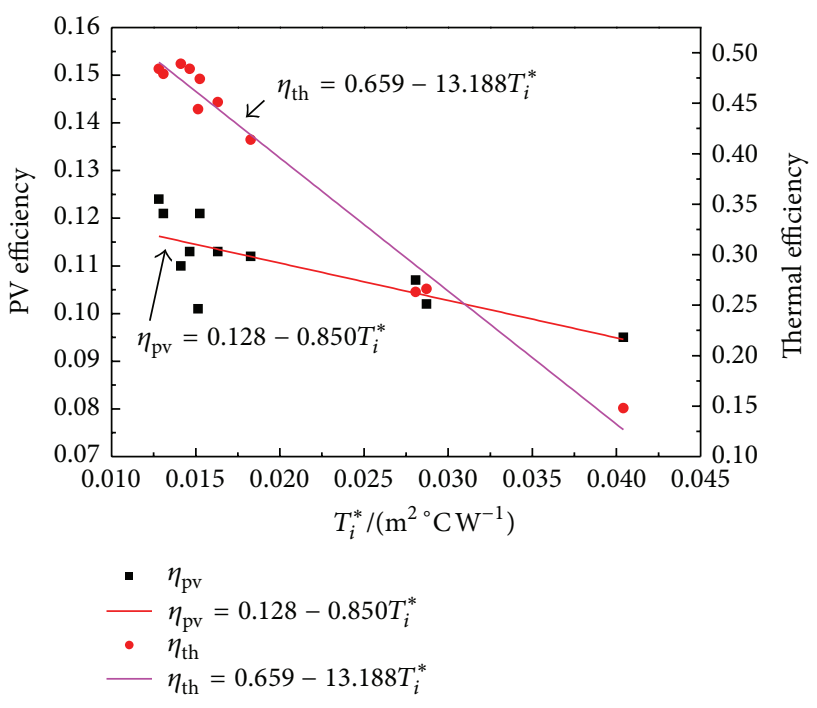

Figure 7: PV efficiency and thermal efficiency fit curves of the experimental results on SPV/T system.

were chosen to illustrate the overall performance, as shown in Table 3.

The PV efficiencies and thermal efficiencies of the SPV/T system in Case 1-Case 11 were fitted to a linear function to correspond to mutual relationships among the variables, as shown in Figure 7.

For the SPV/T system, the PV efficiency under the zero reduced temperature condition was $12.8 \%$, which was reasonable and could be further improved by using the front glazing material with a higher transmissivity. The thermal efficiency intercept was $65.9 \%$, which could also be improved by using selective absorber surface with low emissivity.

4.3. Experiment Error Analysis. The relative error (RE) of the dependent variable $y$ can be calculated as follows:

$$
\begin{gathered}
\mathrm{RE}=\frac{d y}{y}=\frac{\partial f}{\partial x_{1}} \frac{d x_{1}}{y}+\frac{\partial f}{\partial x_{2}} \frac{d x_{2}}{y}+\cdots+\frac{\partial f}{\partial x_{n}} \frac{d x_{n}}{y}, \\
y=f\left(x_{1}, x_{2} \cdots x_{n}\right),
\end{gathered}
$$

where $x_{i},(i=1, \ldots, n)$, is the variable of the dependent variable $y$ and $\partial f / \partial x$ is the error transferring coefficient of the variables.

The experimental relative mean error (RME) during the test period can be expressed as

$$
\mathrm{RME}=\frac{\sum_{1}^{N}|\mathrm{RE}|}{N} .
$$

According to (10)-(11), the RMEs of all variables were calculated and the results were given in Table 4.

\section{Conclusion}

This paper presented a semitransparent photovoltaic/thermal system (SPV/T) with water cooling, which not only could 
TABLE 3: List of experimental results.

\begin{tabular}{|c|c|c|c|c|c|c|}
\hline Parameters & $\begin{array}{c}\text { Initial water } \\
\text { temperature in the } \\
\text { tank }\left({ }^{\circ} \mathrm{C}\right)\end{array}$ & $\begin{array}{c}\text { Average } \\
\text { environmental } \\
\text { temperature }\left({ }^{\circ} \mathrm{C}\right)\end{array}$ & $\begin{array}{c}\text { Average solar } \\
\text { radiation }\left(\mathrm{W} \cdot \mathrm{m}^{-2}\right)\end{array}$ & $\begin{array}{l}\text { Average water flow } \\
\qquad\left(\mathrm{m}^{3} \cdot \mathrm{h}^{-1}\right)\end{array}$ & $\begin{array}{l}\text { PV efficiency } \\
(\%)\end{array}$ & $\begin{array}{l}\text { System thermal } \\
\text { efficiency } \\
(\%)\end{array}$ \\
\hline Case 1 & 20.9 & 12.7 & 520.9 & 0.031 & 0.113 & 0.484 \\
\hline Case 2 & 24.7 & 14.5 & 710.6 & 0.031 & 0.124 & 0.484 \\
\hline Case 3 & 26.2 & 15.6 & 665.2 & 0.031 & 0.121 & 0.474 \\
\hline Case 4 & 28.7 & 17.4 & 778.0 & 0.031 & 0.121 & 0.479 \\
\hline Case 5 & 30.7 & 17.7 & 845.0 & 0.031 & 0.11 & 0.489 \\
\hline Case 6 & 33.3 & 17.9 & 930.8 & 0.031 & 0.101 & 0.444 \\
\hline Case 7 & 35.8 & 18.5 & 979.0 & 0.031 & 0.113 & 0.451 \\
\hline Case 8 & 38.4 & 19.4 & 969.2 & 0.031 & 0.112 & 0.414 \\
\hline Case 9 & 41.6 & 19.5 & 753.5 & 0.031 & 0.102 & 0.266 \\
\hline Case 10 & 43.1 & 19.7 & 806.1 & 0.031 & 0.107 & 0.263 \\
\hline Case 11 & 44.5 & 19.5 & 611.0 & 0.031 & 0.095 & 0.148 \\
\hline
\end{tabular}

TABLE 4: The experimental RME of the variables.

\begin{tabular}{lcccc}
\hline Variable & $T$ & $G$ & $\eta_{\text {sys,pv }}$ & $\eta_{\text {sys,th }}$ \\
\hline RME & $0.066 \%$ & $2.0 \%$ & $4.2 \%$ & $22.79 \%$ \\
\hline
\end{tabular}

provide the electrical power and hot water, but also would attain the natural illumination for the building, and in comparison with the common nontransparent BIPV/T system, it has more advantages.

Based on the experiment results, the PV efficiency and thermal efficiency of the SPV/T system on the sunny day were approximately $11.5 \%$ and $39.5 \%$, respectively. Furthermore, the exergy analysis of the SPV/T system was made to indicate that the PV exergy efficiency was the main portion in the system exergy efficiency, which was because in PV/T system applications the production of electricity is the main priority, and it is necessary to operate the PV modules at low temperature. At the same time, the PV and thermal efficiencies fit curves were made to illustrate the SPV/T system performance comprehensively.

The experiment presented the overall electrical and thermal performances of the SPV/T system and verified the feasibility of it, which indicated a good application prospect.

\section{Conflict of Interests}

The authors declare that there is no conflict of interests regarding the publication of this paper.

\section{Acknowledgments}

The study was sponsored by the National Science Foundation of China (Grant nos. 51178442, 51408578), and "the Fundamental Research Funds for the Central Universities", and China Postdoctoral Science Foundation (2014M550350).

\section{References}

[1] T. T. Chow, G. N. Tiwari, and C. Menezo, "Hybrid solar: a review on photovoltaic and thermal power integration," International Journal of Photoenergy, vol. 2012, Article ID 307287, 17 pages, 2012.

[2] P. Ooshaksaraei, K. Sopian, R. Zulkifli, M. A. Alghoul, and S. H. Zaidi, "Characterization of a bifacial photovoltaic panel integrated with external diffuse and semimirror type reflectors," International Journal of Photoenergy, vol. 2013, Article ID 465837, 7 pages, 2013.

[3] J. H. Kim and J. T. Kim, "The experimental performance of an unglazed PVT collector with two different absorber types," International Journal of Photoenergy, vol. 2012, Article ID 312168, 6 pages, 2012.

[4] T. Matuska, "Simulation study of building integrated solar liquid PV-T collectors," International Journal of Photoenergy, vol. 2012, Article ID 686393, 8 pages, 2012.

[5] N. Sellami, T. K. Mallick, and D. A. McNeil, "Optical characterisation of 3-D static solar concentrator," Energy Conversion and Management, vol. 64, pp. 579-586, 2012.

[6] J.-G. Kang, J.-H. Kim, and J.-T. Kim, "Performance evaluation of DSC windows for buildings," International Journal of Photoenergy, vol. 2013, Article ID 472086, 6 pages, 2013.

[7] K. Vats and G. N. Tiwari, "Performance evaluation of a building integrated semitransparent photovoltaic thermal system for roof and faade," Energy and Buildings, vol. 45, pp. 211-218, 2012.

[8] K. Vats and G. N. Tiwari, "Energy and exergy analysis of a building integrated semitransparent photovoltaic thermal (BISPVT) system," Applied Energy, vol. 96, pp. 409-416, 2012.

[9] K. Vats, V. Tomar, and G. N. Tiwari, "Effect of packing factor on the performance of a building integrated semitransparent photovoltaic thermal (BISPVT) system with air duct," Energy and Buildings, vol. 53, pp. 159-165, 2012.

[10] D. Kamthania, S. Nayak, and G. N. Tiwari, "Performance evaluation of a hybrid photovoltaic thermal double pass facade for space heating," Energy and Buildings, vol. 43, no. 9, pp. 22742281, 2011.

[11] R. Petela, "Exergy of undiluted thermal radiation," Solar Energy, vol. 74, no. 6, pp. 469-488, 2003.

[12] R. Petela, "Exergy analysis of the solar cylindrical-parabolic cooker," Solar Energy, vol. 79, no. 3, pp. 221-233, 2005. 
[13] T. T. Chow, G. Pei, K. F. Fong, Z. Lin, A. L. S. Chan, and J. Ji, "Energy and exergy analysis of photovoltaic-thermal collector with and without glass cover," Applied Energy, vol. 86, no. 3, pp. 310-316, 2009.

[14] T. T. Chow, W. He, and J. Ji, "Hybrid photovoltaicthermosyphon water heating system for residential application," Solar Energy, vol. 80, no. 3, pp. 298-306, 2006. 

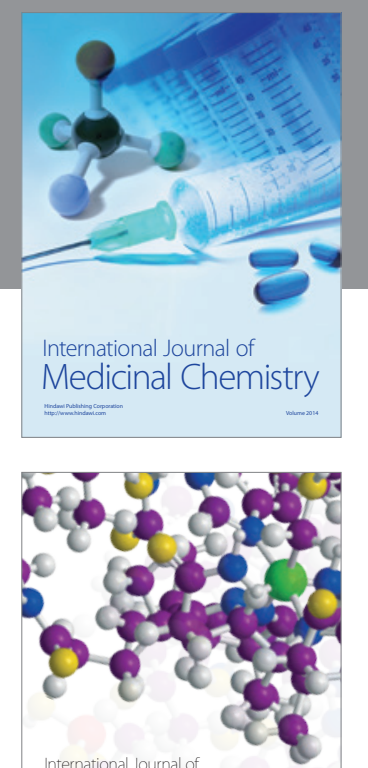

\section{Carbohydrate} Chemistry

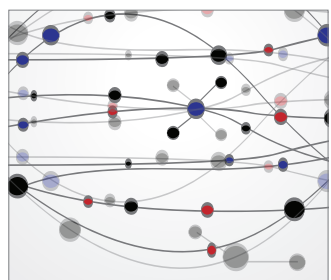

The Scientific World Journal
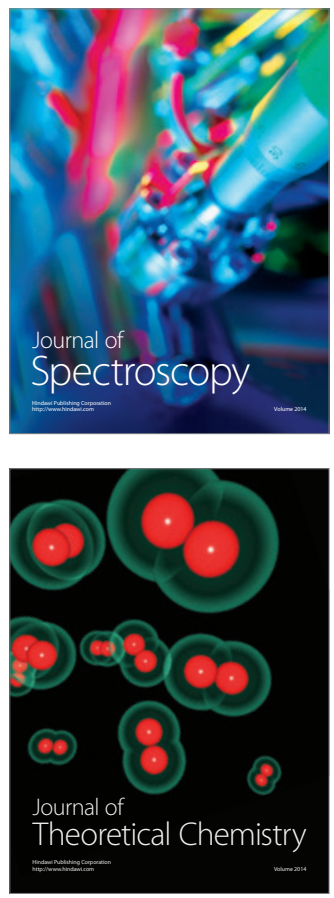
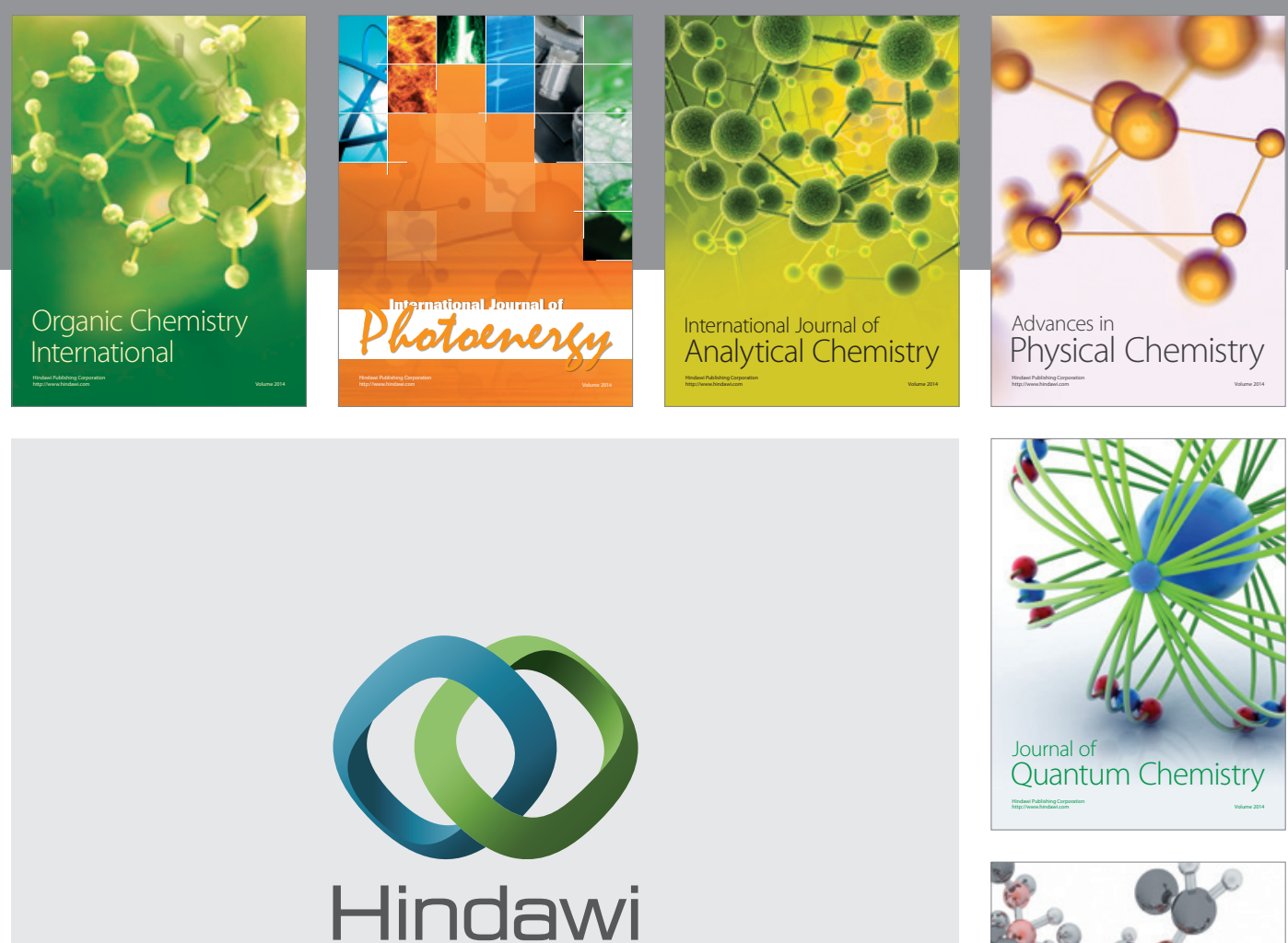

Submit your manuscripts at

http://www.hindawi.com

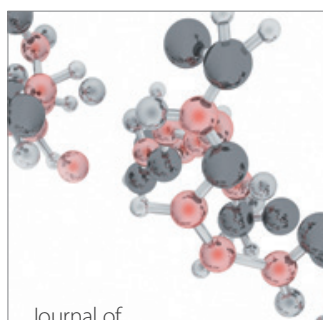

Analytical Methods

in Chemistry

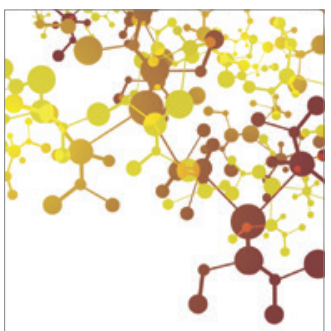

Journal of

Applied Chemistry

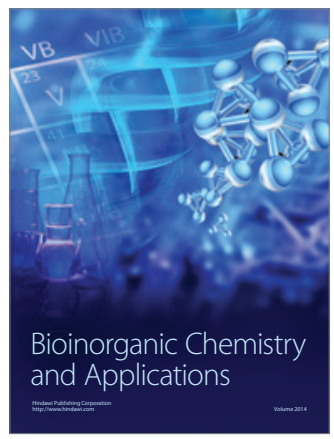

Inorganic Chemistry
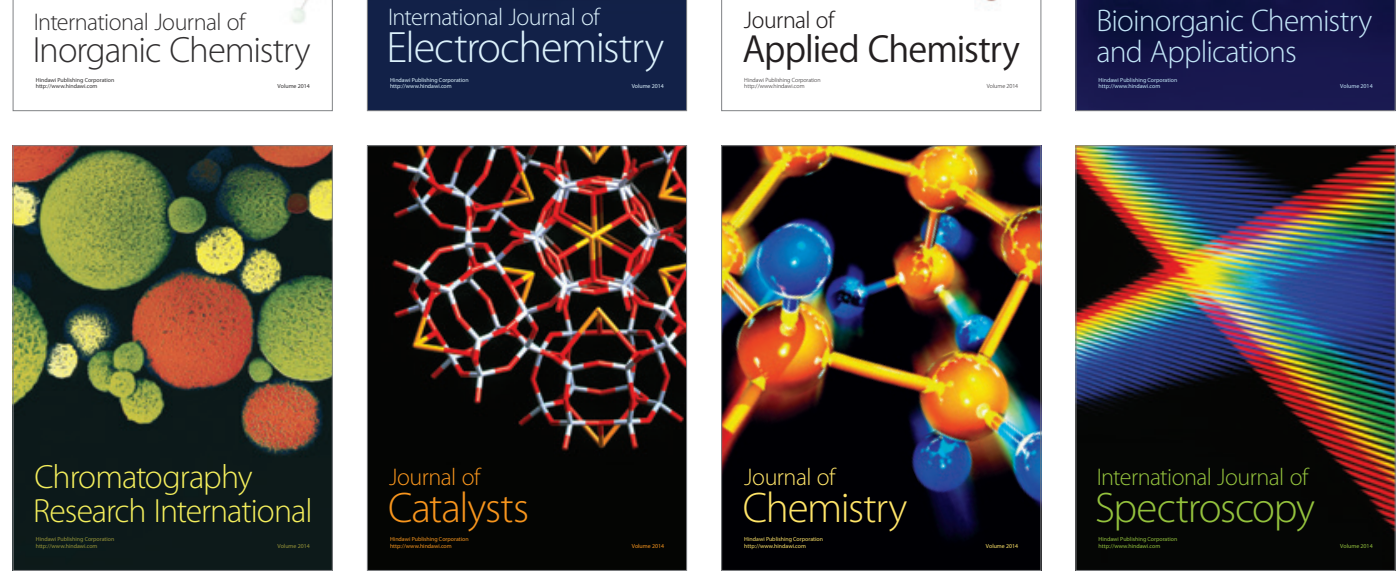